I Universidade de São Paulo (USP), Departamento de Teoria

Literária e Literatura Comparada, São Paulo, SP, Brasil

bru.dellatorre@gmail.com

https://orcid org/0000-0003-4472-8848

Bruna Della Torre'

\title{
DIALÉTICA DA DESUMANIZAÇÃO
}

As portas do céu eram pequenas, ao contrário do que poderia esperar. Precisaria de se abaixar consideravelmente para passar e, na multidão de quem queria ser atendido, era dramática a confusão, gerando violência e uma nuvem de pó que se levantava com muita frequência. O apocalipse dos trabalhadores, Valter Hugo Mãe

É quase um truísmo afirmar que cada época se debruça sobre a literatura orientada por suas próprias questões e, como é o caso de todas as questões óbvias, é bom se lembrar de não as esquecer. Isso não significa afirmar que o caráter clássico de uma obra literária consistiria em algo estático, imutável, que é capaz de falar ao presente, pois se dirige ao "humano". Ao contrário, como lembrava Paul Valéry, é em seu caráter dinâmico que uma obra de arte é capaz de se comunicar com as gerações vindouras, pois contém em si a sua própria crítica, o seu próprio desdobramento.

A pergunta sobre qual é a melhor literatura, entre o que se considera clássico, que configura a vivência da pandemia da covid-I 9 não parece descabida neste momento. Livros como Morte em Veneza, de Thomas Mann - e seu contraponto irônico, A montanha mágica -, A peste, de Albert Camus, Decameron, de Boccaccio, podem servir para refletirmos sobre inúmeras questões a respeito da vida sob clausura, do tempo diante da morte, da claustrofobia e da agorafobia, da relação da moral com a doença. Este é igualmente um momento importante para tirarmos da estante as distopias: o fechamento das fronteiras na Europa, a vigilância da quarentena por drones na China e o controle da população em Taiwan por meio do rastreamento de celulares por Big Data fazem os romances de Huxley e Orwell soar como realismo naturalista. Essas obras nos ajudam a refletir sobre a peste, sobre a quarentena e sobre suas consequências para a sociedade. 
Se a disseminação da doença já é uma tragédia por si mesma, as escolhas políticas que a acompanham parecem, no entanto, ainda mais graves. O lema do Brasil atual é "salve-se quem puder acima de tudo e o capital acima de todos". O país possui hoje mais de $40 \%$ de sua força de trabalho na informalidade e uma grande parcela da população desassistida. A disposição de um grande número de pessoas, incluindo diversos chefes de Estado, de sacrificar uma parte de sua população - aquela que não contribui mais ativamente para o crescimento econômico e que onera o sistema previdenciário - revela a face genocida do capitalismo. À maior parte da população mundial são negados os direitos básicos à saúde e à sobrevivência, e se torna cada vez mais claro quem é supérfluo nesse sistema. Judith Butler (20I5: 64) fala em "vidas não passíveis de luto", Giorgio Agamben (20I0: 26) em "Estado de exceção permanente", Achille Mbembe (2020: I46) em "Necropolítica": todos concordam que o novo arranjo se baseia numa decisão política e econômica sobre quem vive e quem morre. Há trabalhadores aos quais o direito de parar é negado. Muitos deles se ocupam em levar comidas e mantimentos àqueles cujas vidas têm mais valor. Os detentos em cadeias superlotadas, a população em situação de rua, os pobres e miseráveis sem acesso às mínimas condições sanitárias, assim como os idosos, são considerados dispensáveis. Só a vida economicamente útil pode ter esperança. Na Itália, respiradores de idosos foram retirados para salvar os mais jovens. Ninguém quer vestir um terno de madeira, mas imagens mais assustadoras ainda são as das valas comuns, nas quais os indivíduos são desprovidos de qualquer reconhecimento até mesmo na morte.

A indiferença implicada na defesa de chefes de Estado em relação àqueles que perderão suas vidas - não apenas devido a uma tragédia "natural", como a disseminação do vírus, mas devido a decisões políticas - e a recusa de parte da sociedade de se responsabilizar pelo todo fazem renascer um tema clássico, tanto na literatura quanto na teoria social. Por isso, gostaria de sugerir que há uma literatura ainda mais atual para o período que estamos vivendo: aquela que trata da desumanização. O inseto monstruoso de Kafka, os moradores da lata de lixo de Beckett, a loucura do narrador-personagem de Faulkner, e, numa chave mais contemporânea, a aniquilação das empregadas domésticas, dos imigrantes humilhados e ofendidos de Hugo Mãe referem-se previamente ou ex-post facto à barbárie da desumanização dos campos de concentração, da bomba atômica, à transfiguração da consciência pelo horror colonial, à despossessão física e corporal promovida pela precarização do trabalho, mas oferecem igualmente uma contraimagem da sociedade burguesa na sua normalidade, demonstrando que a exceção nada mais faz que revelar a regra. A pandemia de coronavírus que tomou conta do mundo abriu espaço para a contestação dessa "normalidade" da sociedade burguesa novamente, uma vez que a barbárie de seu caráter de exceção expõe as fissuras de nosso modo de vida. 
Fato objetivo da vida social sob o capitalismo, a desumanização é fruto da frieza burguesa. Tema de Marx (20I3), que caracterizou o capitalismo como um processo social em cujo peito não bate um coração; de Simmel (2005), que demonstrou ser a frieza, aliada à abstração e ao cálculo, pré-condição de sobrevivência nas grandes metrópoles; e da Escola de Frankfurt (2006), que a pensou sob a forma do antissemitismo e do holocausto, a frieza burguesa é também o cerne dessa literatura. Gregor Samsa é chutado para fora de casa no momento de maior angústia de sua metamorfose, K., de O processo, e maria da graça, em $\mathrm{O}$ apocalipse dos trabalhadores, têm sua entrada barrada no céu sem razão aparente. Aos desumanizados, o acesso à salvação está bloqueado. As pessoas transformadas em meras sombras de si mesmas em Esperando Godot e Fim de partida aguardam algo ou alguém que não sabem o que ou quem é, num mundo em que a catástrofe já ocorreu. Sua realidade é a do desamparo radical. Os personagens de Faulkner são praticamente desprovidos de subjetividade. $\mathrm{O}$ emaranhado de fios e nós sem forma definida, Odradek, também um personagem de Kafka, é o lixo da sociedade, o seu resíduo. Coisificadas, embrutecidas, aniquiladas, essas criaturas revelam a verdade da sociedade que as produziu.

Aí reside o núcleo de verdade desses autores; eles sabem que o mundo já acabou. Mas de seus romances e peças, no entanto, não brota resignação, mas uma espécie de dialética da desumanização. Eles nos ajudam a perguntar quem são de fato os desumanizados dessa história. Ao expor a desumanização em toda a sua nudez, em toda a sua coisificação, um livro como A metamorfose, por exemplo, suscita a questão de quem é o verdadeiro parasita: Gregor Samsa, o burocrata transformado num inseto ou seus parentes e patrões, que o exploram e o deixam desamparado quando adoece, o funcionário público ou aqueles que querem viver à custa do suor dos outros? (Carone, 2007: 242). Os filmes recentes de Bong Joon-ho, O hospedeiro e Parasita, vão nessa mesma linha.

Os legados da crise que estamos vivendo já se delineiam: vigilância populacional pelo Big Data, crise econômica, acirramento das políticas anti-imigratórias, adesão irrefletida ao modelo online de ensino, defesa do fechamento de fronteiras, retorno a uma soberania nacional esgarçada (especialmente no caso dos países europeus), multiplicação das cercas e da lógica do condomínio, medo do contato físico, entre outros. Caso uma alternativa coletiva e corajosa não apareça, a pandemia pode se tornar um laboratório para um neoliberalismo ainda mais brutal e genocida. Por isso, além de Huxley e Camus, podemos recorrer a Kafka, Beckett e Hugo Mãe para compreender o presente. Sua força negativa pode ser de grande valia para a travessia que temos pela frente e nos dar força para pôr fim de uma vez por todas aos processos sociais que engendram a desumanização. 


\section{REFERÊNCIAS}

Agamben, Giorgio. (2010). Homo sacer: o poder soberano e a vida nua I. Belo Horizonte: UFMG.

Butler, Judith. (2015). Quadros de guerra: quando a vida é passível de luto? Rio de Janeiro: Civilização Brasileira.

Carone, Modesto. (2007). O parasita da família: sobre A metamorfose de Kafka. Literatura e Sociedade, I2/Io, p. 237243.

Marx, Karl. (2013). O capital: crítica da economia política. Livro I. São Paulo: Boitempo.

Mbembe, Achille. (2020). Necropolítica. Arte \& ensaios, 32, p. I23-I5I.

Simmel, Georg. (2005). As grandes cidades e a vida do espírito. Mana, I I/2, p. 577-59I.

Bruna Della Torre é professora substituta na Universidade de Brasília. Doutora em sociologia pela Universidade de São Paulo em 2017 com a tese Adorno, crítico dialético da cultura. Realizou pósdoutorado no Departamento de Teoria Literária e Literatura Comparada da USP (Capes). Editora executiva da revista Crítica Marxista e autora de Vanguarda do atraso ou atraso da vanguarda? Oswald de Andrade e os teimosos destinos do Brasil, "Adorno, leitor de Marx" e "Adorno e o cinema reconsiderado". 


\section{Palavras-chave}

Covid-ig;

literatura;

pandemia;

teoria crítica;

neoliberalismo.

\section{A DIALÉTICA DA DESUMANIZAÇÃO}

\section{Resumo}

O texto busca pensar qual é a literatura que melhor figura o período no qual estamos vivendo, tendo em vista a combinação da pandemia do coronavírus, do autoritarismo e do neoliberalismo de plataformas.

\section{Keywords}

\section{DIALECTICS OF DEHUMANIZATION}

Covid-I9; Abstract

literature;

The text aims to reflect upon the literature that best represents the period in which we live, given the combination pandemics; of the covid-I9 pandemic, authoritarianism, and platform critical theory; neoliberalism. 